\title{
Knowledge Base Program Studi Berbasis Ontologi
}

\author{
Eriya, Rina Septiriana \\ Program Studi Teknik Informatika \\ Politeknik Negeri Jakarta, \\ Depok, Indonesia \\ eriya@tik.pnj.ac.id, rina.septiriana@tik.pnj.ac.id
}

Diterima: 6 Oktober 2017. Disetujui: 10 november 2017. Dipublikasikan: November 2017

\begin{abstract}
Abstrak - Dalam rangka meningkatkan akreditasi program studi dibutuhkan peningkatan kompetensi lulusan, salah satu caranya adalah dengan menghasilkan skripsi mahasiswa yang berkualitas. Berdasarkan pengamatan saat ini, untuk menentukan pembimbing skipsi mahasiswa masih terdapat kendala yang berkaitan dengan korelasi antara kompetensi dosen dan judul yang diangkat oleh mahasiswa. Selain itu seringkali mahasiswa mengangkat tema yang tidak sesuai dengan capaian dari program studi yang bersangkutan. Berdasarkan permasalahan tersebut dibutuhkan sebuah aplikasi Sistem Pendukung Keputusan (SPK) untuk menentukan pembimbing skripsi mahasiswa sesuai dengan kompetensi masingmasing dosen. Salah satu komponen dari sistem pendukung keputusan adalah knowledge base (basis pengetahuan). Knowledge Base dapat digunakan sebagai alat bantu untuk pengambilan keputusan dari SPK. Penelitian ini dilaksanakan pada jurusan Teknik Informatika dan Komputer (TIK) Politeknik Negeri Jakarta, dengan menitikberatkan pada pembuatan basis pengetahuan program studi berbasis ontologi yang bertujuan untuk memperoleh informasi detail mengenai capaian yang diinginkan oleh masing-masing program studi yang ada di jurusan.
\end{abstract}

Kata Kunci: ontologi, knowledge base, program studi.

\section{PENDAHULUAN}

Knowledge Base atau basis pengetahuan dapat dipergunakan sebagai alat bantu untuk pengambilan keputusan dari desicion support system[1]. Penelitian ini menitikberatkan pada pembuatan basis pengetahuan program studi berbasis ontologi yang bertujuan untuk memperoleh informasi detail mengenai capaian yang diinginkan oleh masing-masing program studi yang ada di jurusan. Basis pengetahuan selanjutnya dapat digunakan untuk membangun aplikasi pendukung keputusan (SPK) dalam penentuan pembimbing skripsi yang sesuai dengan kompetensi dosen, selain itu juga dapat digunakan untuk pengecekan terhadap proposal skripsi apakah sudah sesuai dengan capaian program studi atau tidak.

Mengacu pada Permen no. 49, tahun 2014, program studi merupakan kesatuan kegiatan pendidikan dan pembelajaran yang memiliki kurikulum dan metode pembelajaran tertentu dalam satu jenis pendidikan akademik, pendidikan profesi, dan/atau pendidikan vokasi.

Ontologi dapat didefinisikan dalam banyak makna diantaranya dikemukakan oleh Neches bahwa ontologi merupakan pengertian dan relasi kosakata dalam sebuah bidang tertentu menggunakan aturan yang mengkombinasikan antara pengertian istilah yang berkaitan dengan bidang tersebut serta relasi untuk mendefinisikan kosakata tertentu[2] dan menurut Gruber ontologi adalah spesifikasi secara nyata dan detail dari sebuah istilah untuk domain tertentu dan relasi yang terdapat di dalamnya[3].

Pemanfaat ontologi untuk memperoleh basis pengetahuan dimaksudkan untuk membantu komputer dalam menalarkan informasi yang ada sehingga membentuk logika yang menjadi dasar pembentukan basis pengetahuan yang merupakan kumpulan instances dari kelas-kelas yang sudah dibentuk. Adapun tujuan dari penelitian ini adalah untuk membangun bagian dari basis pengetahuan yang akan digunakan dalam pembuatan aplikasi sistem pendukung keputusan penentuan dosen pembimbing skripsi.

\section{TINJAUAN PUSTAKA}

\section{A. Text Mining}

Text mining adalah sebuah proses ekstraksi informasi yang dianggap menarik dan penting dari sebuah dokumen teks[4]. Rangkaian proses dalam text mining dimulai dari proses pengumpulan dokumen yang dianggap sesuai dengan informasi text mining yang dibutuhkan. Setelah dokumen tersebut dikumpulkan, selanjutnya dilakukan preprocesing untuk memeriksa format dan karakter yang ada dalam dokumen tersebut. Tahapan selanjutnya adalah fase dari text analysis dimana dilakukan analisis semantik untuk menghasilkan informasi yang berkualitas. Adapun proses dari text mining dapat dilihat pada Gambar 1. 


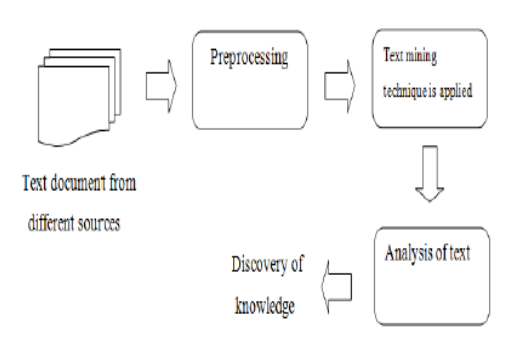

Gambar 1.Proses Text mining[4]

Dalam proses text mining untuk membuat komputer mengerti dengan dokumen ataupun teks terdapat beberapa teknik yang digunakan antara lain adalah information extraction, summarization, categorization, clustering and information visualization. Teknik - tekn ik yang digunakan dalam text mining adalah sebagai berikut: [4]

1. Ekstraksi Informasi

Ekstraksi Informasi adalah langkah awal dalam text mining untuk menganalisis teks yang tidak terstruktur dengan cara mengidentifikasi frase kunci dan hubungan yang ada di dalamnya. Ekstraksi Informasi meliputi tokenisasi, identifikasi nama entitas, segmentasi kalimat dan part-of-speech assignment.

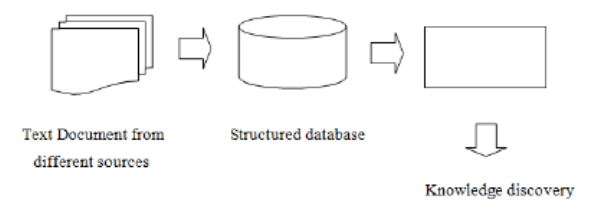

Gambar 2. Proses Ekstraksi Informasi

Pada Gambar 2 dapat dilihat bahwa fase dari ekstraksi Informasi meliputi proses parsing dari kalimat maupun frase kemudian diinterpretasikan secara semantik dan informasi yang dibutuhkan akan dimasukkan ke dalam basis data sebagai sebuah pengetahuan.

\section{Kategorisasi}

Kategorisasi merupakan metode supervised learning dengan menggunakan contoh input-output yang dikategorikan dari dokumen free text untuk mengklasifikasikan dokumen baru. Proses dari kategorisasi teks terdiri dari pre-processing, pengindeks-an, pengurangan dimensional, dan klassifikasi. Tujuan dari kategorisasi adalah untuk melatih classifier dari contoh yang sudah diketahui untuk mengkategorisasi contoh yang belum diketahui secara otomatis. Teknik kategorisasi teks yang dapat digunakan untuk klasifikasi statistik antara lain Naive Bayesian classifier, Nearest Neighbour classifier, Decision Tree, dan Support Vector Machines.

\section{Clustering}

Clustering merupakan metode untuk mengelompokkan grup dokumen dengan konten yang mirip. Keluaran dari clustering berupa sebuah cluster yang terdiri dari sejumlah dokumen. Dasar dari algoritma clustering adalah membuat vektor dari topik untuk setiap dokumen dan mengukur seberapa besar bobot yang sesuai untuk setiap cluster.

\section{Visualis asi}

Visualisasi merupakan metode yang digunakan memvisualisasikan dokumen dengan meletakkan sumber teks dalam visual hirarki. Adapun secara umum visualisasi digambarkan pada Gambar 3.

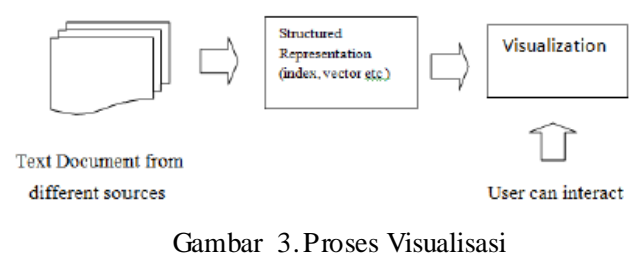

Tujuan dari visualisasi informasi meliputi persiapan data dengan memperoleh data asli dari visualisasi dan membentuk data space, analisis dan ekstraksi data, dan pemetaan visualisasi data space ke data target.

\section{Summarization/Peringkasan}

Peringkasan teks merupakan sebuah proses untuk mengurangi panjang dan detail dari sebuah dokumen dengan mempertahankan poin penting dari dokumen tersebut dan artinya secara umum. Tahapan proses dalam peringkasan dapat dilihat pada Gambar 4.

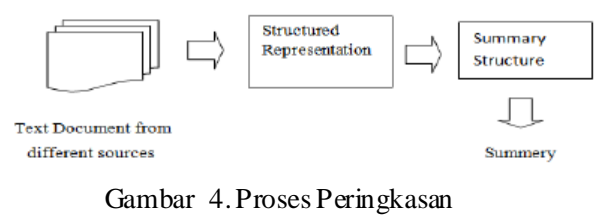

Proses peringkasan dimulai dari preprocessing untuk memperoleh representasi terstruktur dari teks aslinya, kemudian menggunakan algoritma teks terstruktur untuk memperoleh ringkasan yang dijadikan hasil akhir dari proses peringkasan.

\section{B. Ontologi}

Ontologi menurut Nugroho (2012) teori yang membahas mengenai makna dan properti dari sebuah objek dan keterkaitan yang terjadi di dalamnya[5]. Komponen dari ontologi menurut Noy dan McGuinness adalah instance, slot dan kelas[5]. Kelas menjelaskan mengenai konsep dari domain tertentu yang di dalamnya bisa memiliki subkelas 
sebagai penjelasan detail untuk setiap superclassnya, misalnya terdapat sebuah kelas wine yang menerangkan konsep dari wine dan wine memiliki detail pembagian atau subkelas yang terdiri dari whitewine, redwine dan rosewine. Slot merupakan properti dari sebuah kelas dimana slot tersebut merepresentasi frame-knowledge yang di dalamnya terdapat instances (kejadian), misalnya terdapat sebuah jenis wine Chetau Lafite Rothschild Punillac yang diproduksi oleh pabrik Chetau Lafite Rothschild. Berdasarkan instances tersebut terdapat dua buah slot yaitu body (nama wine secara fisik) dan slot maker (pembuat wine), selain itu juga terdapat slot lain slot selera (flavour), bentuk (body), kadar gula (sugar level), pembuat wine (maker) dan seterusnya[5].

\section{C. $T F-I D F$}

Metode TF-IDF merupakan metode untuk menghitung bobot setiap kata. Metode ini akan menghitung nilai Term Frequency (TF) dan Inverse Document Frequency (IDF) pada setiap token (kata) di setiap dokumen dalam korpus dengan menggunakan persamaan (1) [6]:

$$
w_{i j}=t f_{i j} \times i d f_{j}
$$

Keterangan:

$w_{i j}$ adalah bobot term $t_{j}$ terhadap dokumen $d_{i}$

$\mathrm{t} f_{i j}$ adalah jumlah kemunculan term $t_{j}$ dalam dokumen $d_{i}$

$i d f_{j}$ adalah jumlah dokumen yang mengandung term $t_{j}$ (minimal ada satu kata yaitu term $t_{j}$ )

\section{Similarity Cosine}

Similarity Cosine adalah perhitungan kemiripan yang cukup populer dalam perhitungan kemiripan dokumen. Similarity Cosine dilakukan dengan memperbandingkan istilah-istilah yang ada dalam sebuah dokumen dalam bentuk vektor untuk melihat besar nilai kemiripan dokumen tersebut dengan menggunakan persamaan (2)[6]:

$$
\mathrm{S}(\mathrm{q}, \mathrm{d})=\frac{\mathrm{q} \cdot \mathrm{d}}{|\mathrm{q} \| \mathrm{d}|}
$$

E. Knowledge Based-Decision Support System $(K B-D S S)$

Knowledge Based System dalam DSS menurut Giboney dkk. (2015) dapat membantu proses pengambilan keputusan jika memiliki tingkat akurasi yang tinggi[7]. Perkembangan teknologi yang cukup pesat untuk membangun basis pengetahuan dalam ontologi dapat menggunakan tool Protege dimana tidak hanya berfungsi sebagai editor kelas dan properti namun juga dapat melakukan akuisisi pengetahuan dari data mentah[8].

Menurut Liu dkk. (2015) knowledge based dapat dipergunakan sebagai alat bantu untuk pengambilan keputusan dari desicion support system [1]. Pada KB-DSS terdapat beberapa komponen pendukung yaitu knowledge based dan mesin inferensinya ditambahkan dengan 3 komponen dasar DSS yaitu database management sub-system (DBMS), model base management sub-system (MBMS) dan user interaction management subsystem (HCI) yang dapat dilihat pada Gambar 5

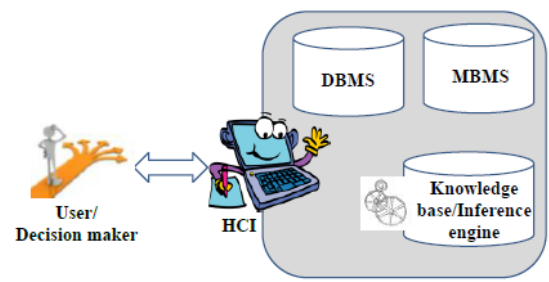

Gambar 5. Komponen Inti KB-DSS[1]

\section{HASIL DAN PEMBAHASAN}

\section{A. Analisis dan Perancangan Ontologi}

1. Penentuan domain dan cakupan ontologi.

Domain yang digunakan adalah domain yang berkaitan dengan istilah di bidang Teknik Informatika dan Komputer dengan cakupan dokumen diambil RPS (Rencana Pembelajaran Semester) yang cakupannya terbagi berdasarkan KBK yang digunakan oleh masing-masing program studi dan data mata kuliah yang diambil oleh setiap program studi. Cakupan ekstraksi informasi yang diambil dari dokumen RPS adalah capaian pembelajaran tiap pertemuan dan bahan kajian atau pokok bahasannya. Sedangkan data mata kuliah digunakan untuk pembentukan subkelas pada setiap kelas yang dibentuk.

Pada jurusan TIK (Teknik Informatika dan Komputer) Politeknik Negeri Jakarta terdapat tiga program studi yaitu

a) Teknik Informatika (TI)

b) Teknik Multimedia Digital (TMD)

c) Teknik Multimedia Jaringan (TMJ)

Masing-masing Program studi mempunyai kurikulum yang berisi mata kuliah yang harus diambil untuk program studi tersebut.

Sedangkan Kelompok Bidang Keilmuan (KBK) yang dimiliki o leh Jurus an ada 6 KBK yaitu :

1. KBK Rekayasa Perangkat Lunak (RPL)

2. KBK Multimed ia

3. KBK Jaringan

4. KBK Embedded

5. KBK Character Building

6. KBK Kesehatan, Keselamatan, dan Keamanan Kerja (K3)

Dari enam KBK tersebut yang diambil sebagai domain ontologi program studi ada 4 
(empat) yaitu Rekayasa Perangkat Lunak (RPL), Multimedia, Jaringan, dan Embedded.

2. Mengenumerasi istilah-istilah yang penting di dalam ontologi

Untuk mengenumerasi istilah-istilah yang penting digunakan metode ekstraksi informasi secara sintaktis dengan melakukan tokenisasi per frase dan mengidentifikasi entitasnya untuk membentuk sebuah basis data yang terstruktur. Pada penelitian ini keyword penting dalam ontologi dienumerasi dari materi yang ada dalam setiap mata kuliah.

3. Mendefinisikan setiap kelas dan hierarki dari kelas tersebut

Hasil enumerasi istilah yang dilakukan pada tahap ke 3 digunakan untuk membentuk kelas dan hierarkinya. Pembentukan ontologi dilakukan dua tahap yaitu pembentukan ontologi program studi dan pembentukan ontologi KBK. Untuk mendefenisikan kelas dan hierarki pe mbentuk ontologi program studi digunakan tool Protege. Terdapat dua domain ontologi, maka ada 2 ontologi terbentuk yaitu :

1) Ontologi KBK terd iri dari
a. Kelas Rekayasa Perangkat Lunak (RPL)
b. Kelas Multimedia
c. Kelas Jaringan
d. Kelas Embdeed

Masing-masing kelas tersebut akan diuraikan lagi menjadi subkelas mata kuliah dan pokok bahas annya.

2) Ontologi Program studi terdiri dari
a. Kelas TI
b. Kelas TMD
c. Kelas TMJ

Masing-masing kelas tersebut akan diuraikan lagi menjadi subkelas mata kuliahnya.

\section{Mendefinisikan properti dari setiap kelas}

Untuk mendefinisikan properti dari setiap kelas dibutuhkan yang berkaitan dengan ciri yang menggambarkan informasi mengenai kelas tersebut secara lebih detail, misalkan properti dari masingmasing program studi dapat dikaitkan dengan definisi program studi secara umum, minat dan kemampuan mahasiswa pada program studi tersebut. Pada perancangan ontologi ini properti yang didefinisikan berupa keterhubungan antara kelas dan subkelasnya, dimana hubungan tersebut berupa saling memiliki. Seperti KBK memiliki mata kuliah, Mata kuliah memiliki pokok bahasan.

\section{Mendefinisikan aspek dari setiap slot}

Pada tahap ini ditentukan aspek dari setiap kelas berupa keyword yang terdapat dari masing- masing subkelas (hirarki terendah) contoh pada kasus ini adalah Domain KBK terdiri dari kelas Multimedia, kelas Multimedia terdiri dari subkelas Mata kuliah Pengantar multimedia. Pada subkelas Pengantar Multimedia didefenisikan aspek-aspeknya berupa pokok bahasan yang dipelajari pada mata kuliah tersebut.

\section{B. Implementasi}

Setelah dilakukan analisis dan perancangan, maka tahapan selanjutnya adalah implementasi untuk menghasilkan form OWL yang merupakan bentuk dari form ontologi dengan menggunakan tool Protege dan Java netbeans sebagai alat bantu ekstraksi informasi dan juga proses pencocokan ontologi antara program studi dan KBK. Berikut ini merupakan potongan file OWL untuk Ontologi Program Studi.

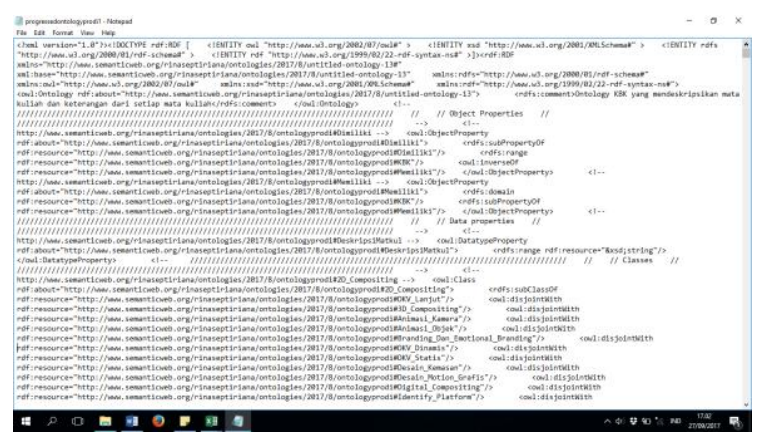

Gambar 6. File OWL untuk Ontologi Program Studi

\section{Pencocokan Ontologi}

Setelah dibuat ontologi program studi dan ontologi KBK selanjutnya dilakukan proses pencocokan ontologi dengan menggunakan algoritma PROMPT dimana prosesnya dimulai dari proses updating otomatis dimana ontologi yang ada dibandingkan, kemudian dicari konfliknya dan kemudian memberikan saran langkah apa yang harus dilakukan. Adapun langkah-langkah dari pencocokan ontologi adalah sebagai berikut :

1. Melakukan input ontologi KBK dan ontologi prodi yang dapat dilihat pada Gambar 7 .

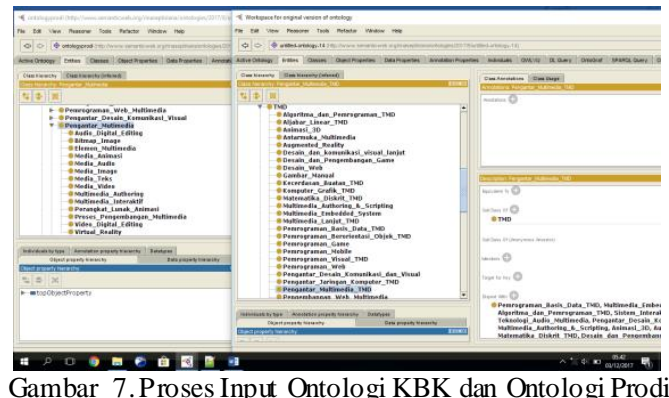


2. Selanjutnya dilakukan proses ontology matching untuk membandingkan antara kedua ontologi dan didapatkan beberapa kesamaan untuk selanjutnya dilakukan proses merging. Dalam proses ontology matching ini, digunakan ontologi prodi sebagai baseline axiom-nya untuk kemudian dibandingkan dengan ontologi KBK. Adapun hasil yang didapatkan dapat dilihat pada Gambar 8.

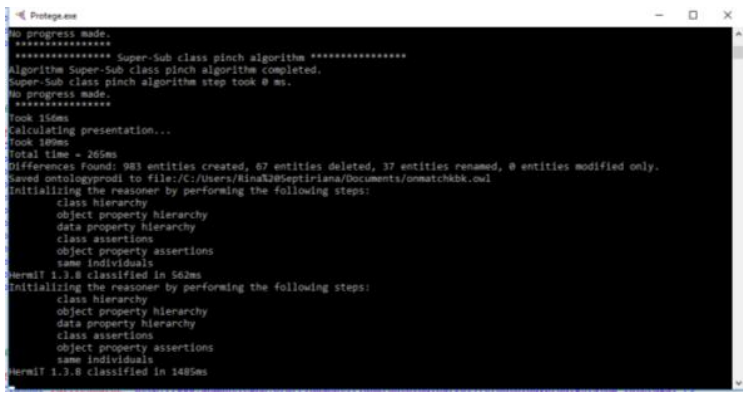

Gambar 8. Ontologi Matching dengan Ontologi Prodi sebagai Baseline

3. Dari hasil ontology matching tersebut didapatkan ontologi baru yang ontologi differences-nya dapat dilihat pada Gambar 9.

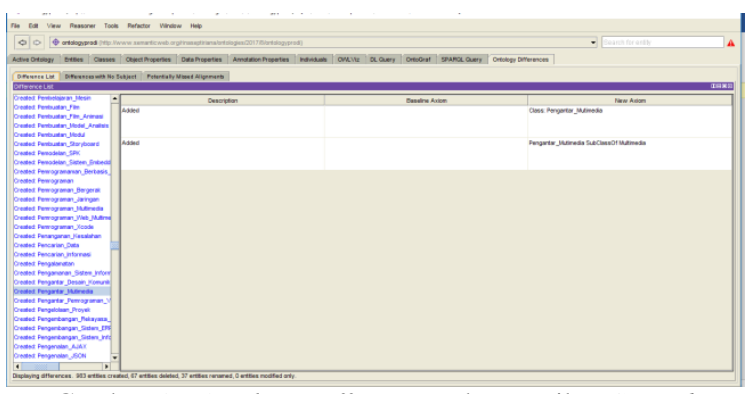

Gambar 9. Ontology Difference pada Tampilan Created Pengant ar Mult imedia

4. Hasil ontologi baru tersebut di-export menjadi file rdf/xml yang dapat dilihat pada Gambar 10 dan Gambar 11.

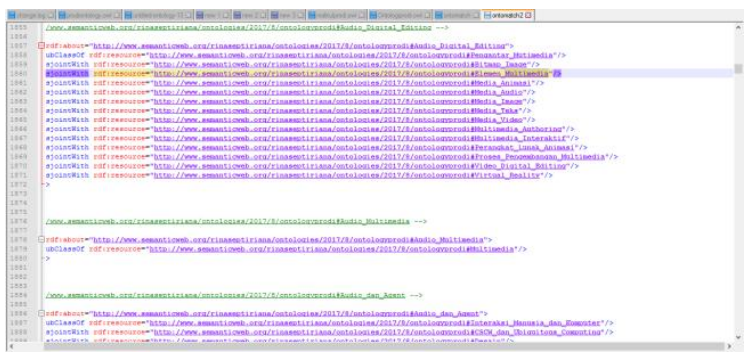

Gambar 10. File Rdf/Xml Hasil Ontology Matching dengan Ontologi Prodi sebagai Baseline

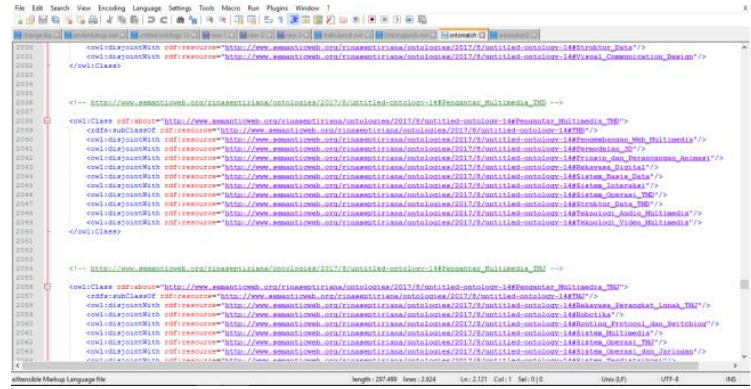

Gambar 11. File Rdf/Xml Hasil Ontology Matching dengan Ontologi Kbk sebagai Baseline

\section{KESIMPULAN}

Berdasarkan analisis dan pembuatan ontologi Program Studi dan Ontologi KBK sebagai basis pengetahuan (Knowledge Base), maka dapat disimpulkan sebagai berikut :

1. Penelitian ini menghasilkan Ontologi KBK dan Ontologi Prodi.

2. Ontologi KBK memetakan mata kuliah untuk setiap KBK dengan deskripsi mata kuliah tersebut.

3. Ontologi Prodi memetakan mata kuliah yang diambil untuk setiap Prodi.

4. Ontology matching antara ontologi KBK dan ontologi Prodi menghasilkan 2 buah File RDF /XML yang akan digunakan sebagai knowledge base untuk sistem pendukung keputusan penentuan dosen pembimbing skripsi.

5. Berdasarkan pengujian terhadap hasil ontology matching yang terbentuk terdapat beberapa entitas yang tidak sesuai dengan kebutuhan knowledge base, sehingga perlu dilakukan analisis yang lebih detail.

\section{REFERENSI}

[1] Liu, S., Hudson Smith, M., Tuck, S., Pan, J., Alkuraiji, A. and Jayawickrama, U., 2015. Where can knowledge-based decision support systems go in contemporary business management-a new architecture for the future. Journal of Economics, Business and Management, 3(5), pp.498-504.

[2] Enabling Technology for Knowledge Sharing Robert Neches, Richard Fikes, Tim Finin, Thomas Gruber, Ramesh Patil, Ted Senator, and William R. Swartout, AI Magazine. Fall 1991

[3] Groß, A., Pruski, C., dan Rahm, E. 2016. Evolution of biomedical ontologies and mappings: Overview of recent approaches. Computational and Structural Biotechnology Journal, 14, 333-340.

[4] Gaikwad, S.V., Chaugule, A. dan Patil, P., 2014. Text mining methods and techniques. International Journal of Computer Applications, 85(17).

[5] Nugroho, A., 2012. Membangun Ontologi Jurnal Menggunakan Protege. Jurnal Transformatika, 10(1), pp. 20-25.

[6] Maarif, A.A., 2015. Penerapan Algoritma TF-IDF Untuk Pencarian Karya Ilmiah. Skripsi, Fakultas Ilmu Komputer.

[7] Giboney, J. S., Brown, S. A., Lowry, P. B., \& Nunamaker, J. F. 2015. User acceptance of knowledge-based system 
recommendations: Explanations, arguments, and fit. Decision Support Systems, 72, 1-10.

[8] Tudorache, T., Nyulas, C., Noy, N. F., dan Musen, M. A

2013. WebProtégé: A collaborative ontology editor and knowledge acquisition tool for the web. Semantic web, 4(1), 89-99. 